\title{
Storage Related Changes in Strawberry added Ghee based Low-Fat Spread
}

\author{
Londhe-Patil Prajakta Balasaheb ${ }^{1 *}$, D. D. Patange ${ }^{2}$, Suchita Bhosale ${ }^{3}$, \\ M. M. Yadav' and S. J. Gaondhare ${ }^{1}$
}

${ }^{1}$ Department of Dairy science, Rajarshri Chhatrapati Shahu Maharaj, College of Agriculture, Kolhapur, India

${ }^{2}$ Rajarshri Chhatrapati Shahu Maharaj, College of Agriculture, Kolhapur, India

${ }^{3}$ Department of Animal Husbandry and Dairy Science, MPKV Rahuri University., Ahmednagar, India

Rcsm College of Agriculture, Kolhapur, India

Mahatma Phule Krishi Vidyapeeth, Rahuri, Maharashtra- 413 722, India

*Corresponding author

\section{A B S T R A C T}

\section{Keywords}

Low-fat spread, strawberry, Sensory evaluation, Physicochemical properties, Microbial qualities

Article Info

Accepted:

04 September 2019

Available Online:

10 October 2019
Storage conditions were known to bring about some physicochemical changes in the products. The present investigation was therefore carried out to examine the effect of storage period on the sensory, physicochemical and microbiological quality of low fat spread. Low fat spread without strawberry powder and synthetic preservative $\mathrm{T}_{1}$ (Control), Low fat spread with strawberry powder but without preservative $T_{2}$ (SS),Low fat spread with synthetic preservative $T_{3}$ (Preservative) were prepared and subjected to 100 days of storage and evaluated periodically at intervals of 20 days. With the progress in the storage period total solid decreases while $\mathrm{pH}, \mathrm{FFA}$, TBA, peroxide value, oiling off, wheying off increases. From the point of view of colour and appearance, body and texture, flavor, spreadability and overall acceptability, the SS product was acceptable 60 days of storage none of these rendered the product unacceptable for the 60 days at $5^{\circ} \mathrm{C}$.the main cause of spoilage, especially in control sample, was found to be surface growth of yeasts and moulds. SPC in all samples increased and coliform count of the samples was found to be nil through the storage period which good hygienic condition during manufacture and storage of the product. The shelf life of the product was found to considerably influence by the presence of preservative.

\section{Introduction}

The fat in milk is primary to provide a source of energy to the new born baby. Dairy products, particularly higher-fat dairy products are considered significant sources of energy in the diet of vegetarian population too (Feeney et al., 2017). The milk fat products could be 
divided into several categories according to their fat contents, including anhydrous milk fat products, butter, cream and dairy fat spreads. Recently variety of dairy and nondairy spreads is available on the customer's door. These spreads may be to increase the content of unsaturated fatty acids for improvement of spreadability at low temperatures (Lee et al., 2018).

Spreads are the products harmonizing with the idea of healthy nutrition. At the same time they have good taste and flavor as well as very good spreadability at refrigerator temperature and retain its stand up property even at high ambient temperature (Dostalova2003). Spreads have low caloric content than butter and blends easily with other foods for convenience in cookery and serving. Both the dietary and convenience requirements of the consumer have been required by table spreads. Commercial table spreads now exists that contain fat level ranging from a high of 80 per cent all the way down to 0 per cent. Products resembling margarine containing less than 80 per cent fat are usually called spreads. As per regulations in some countries, only products containing less than 80 per cent but more than 40 per cent fat, $40-70$ per cent fat, $62-80$ per cent fat, or less than 75 per cent fat are labeled as spreads. Products with 60-80 per cent fat or with 41-60 per cent fat are 'reduced-fat' spreads and products containing less than 40 per cent are referred to as 'low-fat' spreads. The term 'very low-fat' spreads is used for spreads of 5-15 per cent fat and even less. The spreads with extremely low-fat content are sometime called 'Ultra low-fat' spreads. Lowfat spread, generally contain 30-50 per cent moisture, 30-50 per cent fat and 8-12 per cent solids-not-fat (Dostalova2003). It can be manufactured from different types of fat (viz. butterfat, vegetable fat or other animal fat), protein (milk proteins e.g. skim milk, buttermilk, whey or their concentrated forms, sodium caseinate, calcium reduced skim milk powder, ultrafiltered protein concentrate, whey protein concentrate etc.) and using additives like stabilizers, emulsifiers, plasticizers, emulsifying salts, vitamins, colorants and flavoring material. Considerable efforts have been made in India for development of fat spreads of dairy and nondairy type using a variety of ingredients viz, butter, butter oil, cream, paneer, channa, cheese, vegetable fat and ghee (Patange2006).

The exploitation of ghee in the manufacture of low fat spread is the need of today's dairy industry due to its easy availability and better shelf life at ambient temperature. (Patange et $a l ., 2015)$ utilized ghee in general as a source of fat in the manufacture of low fat spread.

Ghee is a fat rich dairy product widely used in India since time immemorial. It has been an integral part of our culture. Ancient Sanskrit literature describes Ghee (Ghrita) as the food fit for Gods and commodity of enormous value. Nutritionally, ghee is a superior dairy product. Apart from a concentrated source of energy, it is also a good source of essential fatty acids, fat soluble vitamins like A, D, E \& $\mathrm{K}$ and it also forms essential structural components of the cell membrane. With regards to digestibility, absorption and growth, it has been found that ghee lies in the completely digestible class of fat. It can therefore be an important dietary constituent for the patients having diseases of stomach, intestinal tract, liver, kidney, gall bladder (Toyabhai2012).

Despite of its numerous health benefits, over the past few years, ghee has received adverse publicity due to its cholesterol and saturated fatty acid contents. Both have been negatively implicated as perpetrators of arteriosclerosis (Sharma et al., 2010) hence hypertension. From the nutritionist's point of view, the removal of a whole food group from the diet, such as ghee simply to avoid cholesterol and 
saturated fatty acids is illogical and creates more difficulty for Indian people where ghee plays an important role in their diet (Parmar and Khamrui 2017).

Consumption of phyto-chemical-rich foods such as fruits, vegetables are associated with a reduced risk of diseases mediated by oxidative stress and inflammation such as certain cancers, atherosclerosis and neurodegenerative diseases (Larsson et al.,2006). Berry fruits are reported to contain a wide variety of phenolics including hydroxybenzoic and hydroxycinnamic acid derivatives, anthocyanins, flavonols, flavanols, condensed tannins (proanthocyanidins) and hydrolyzable tannins (Machiex et al., 1990). Strawberry is an important fruit of family Rosaceae. Occupies an important place among the small fruit plants and is grown throughout the world. Deep red in colour with unique shape, highly perishable fruit has a pleasant flavour. It is rich in vitamin $\mathrm{C}$, sugar, organic acids anthocyanin, phosphorus, iron, other minerals, vitamins, etc. and its desirable flavour is characterized as fruity, sweet and tart. It is utilized for the production of purees, juice concentrate, juice, jams, preserves and rose red wine, (Sharma et al., 2009) strawberries (Fragariax ananassa) is one of the most popular fruit worldwide, with the high unique and desirable flavour. The main characteristics associated with the quality of ripe strawberries are their texture, and presence volatile compounds (Jiawei et al., 2019) strawberries are widely known for their potential health benefits due to their high fiber, potassium, vitamin $\mathrm{C}$ and folate contents. Strawberries are also a very good source of blood sugarregulating dietary fibers (pectins, celluloses, etc.) and thyroid health-promoting iodine. Strawberry fruits are rich in sugars (mainly glucose and fructose, with smaller amounts of sucrose) and acids. Strawberry is good source vitamin $\mathrm{C}$. It has been proved that vitamin $\mathrm{C}$ and phenolic compounds contribute to antioxidant capacity of fruits, as they act as oxygen radical scavengers and may exhibit beneficial health effects (Yildiz et al.,2014)Strawberries are rich in potassium (the most abundant mineral), calcium and magnesium. They are also a good source of folate, omega-3 fatty acids, vitamin B6, and vitamin $\mathrm{K}$, as well as energy-promoting vitamins B2 and B5 (Milivojevic et al., 2010).

However, ripe strawberry is highly perishable mainly because of the smooth texture, high softening and respiration rate, as well as being proved to fungal attacks and off flavour development (Lara et al., 2004). Therefore it needs to utilize properly in different food items including low-fat spread.

Considering the nutritional, therapeutic and antioxidant properties of strawberry and use of ghee in low fat spread preparation, it is planned to use the strawberry in the preparation of ghee based low-fat spread.

\section{Materials and Methods}

Fresh cow milk ghee was obtained from the local market of Kolhapur city. Spray-dried skimmed milk powder (SMP) was obtained from Kolhapur District Milk Producer Union Limited (Gokul), Kolhapur. Navel variety of strawberry fruit was procured from the local market of Kolhapur City. Carragenan- Type II Iota-carrageenan M/S (Hi Media) was used as stabilizer to make the emulsion stabilized. Sorbitol obtained from M/S Qualigens Fine Chemical, Mumbai and was used as plasticizer to improve the spreadability of the low fat spread. Polyoxyethylene sorbitanmonoleate (Tween-80) of (S.D Fine-chem. Ltd) emulsifier was used to make the emulsion strong. Iodized common salt was procured from the local market of Kolhapur city. Citric acid was purchased from M/S. Qualigens Fine chemical, Mumbai used for maintaining the $\mathrm{pH}$ of low fat spread. 


\section{Preparation of strawberry powder}

The Strawberry were procured from local market of Kolhapur and brought to Laboratory of Department of Animal Husbandry and Dairy Science, RCSM College of Agriculture, Kolhapur. The strawberry fruits were washed under running potable tap water. Then, fruits were blanched in boiling water for 3 to 5 minutes. After blanching the fruits were cut into four pieces and were kept for drying at 55 ${ }^{\circ} \mathrm{C}$ for 18 hours (Olubunmi et al., 2013). The dried strawberry fruit pieces were grinded into powder using a kitchen mixer blender. The powder obtained was passed through $1 \mathrm{~mm}$ stainless steel sieve. The sieved strawberry powder was sealed in plastic bags, at room temperature for further use.

\section{Preparation of low-fat spread using cow} milk ghee added with strawberry

Low-fat spread from cow milk ghee was prepared as per protocol developed by Patange (2006) in planetary Mixer. The procedure involves separate preparation and tempering of fat and serum phases before blending and emulsifying them. For preparation of fat phase ghee was heated up to $50^{\circ} \mathrm{C}$ and then added with the emulsifier. It was then heated (in a water-bath) to $70^{\circ} \mathrm{C}$ before being rapidly cooled to $20^{\circ} \mathrm{C}$ (rate of cooling, $12^{\circ} \mathrm{C} / \mathrm{min}$ ) with continuous agitation in a chilled waterbath $\left(2.5^{\circ} \mathrm{C} \pm 1^{\circ} \mathrm{C}\right)$ and subsequently to $5^{\circ} \mathrm{C}$ by quiescent holding in a refrigerator for an overnight period. The cooled fat phase was then tempered to the blending temperature of $25^{\circ} \mathrm{C} \pm 1{ }^{\circ} \mathrm{C}$ by holding in room temperature for $6 \mathrm{~h}$ before use.

Skimmed milk powder as a source of MSNF was dispersed in water together with soluble ingredients followed by mixing with an electric blender, preheating $\left(55^{\circ} \mathrm{C}\right)$, filtration (double- fold muslin cloth), pasteurization $\left(72^{\circ} \mathrm{C}\right.$ for $\left.15-20 \mathrm{sec}\right)$, cooling in an ice water- bath to $20^{\circ} \mathrm{C}$, Before transferring in the aqueous phase in refrigerator it was added with strawberry in different forms as per the treatments. The aqueous phase was remained kept for overnight period of time at refrigerator temperature $\left(5^{\circ} \mathrm{C}\right)$. The selected variety, form and quantity of strawberry was added in the aqueous phase as per treatments. Finally, when required this aqueous phase was acidulated using a dilute citric acid to the desired $\mathrm{pH} 5.2$ (30 min before blending) and warmed it to blending temperature.

The tempered fat phase was transferred to the bowl of planetary mixer and creaming was carried out using the flat beater attachment of the mixer for $30 \mathrm{sec}$ at 'medium' speed. The serum phase was added in three equal installments. Blending was carried out after each addition of the serum phase using medium speed for $30 \mathrm{sec}$. The spreads was packed in $75 \mathrm{gm}$ in plastic cups and closed with lids before being transferred to refrigerator $\left(5^{\circ} \mathrm{C}\right)$.

\section{Sensory evaluation}

Sensory evaluation of strawberry added ghee based low-fat spread samples were carried out by a semi-trained panel of judges from the staff of the Division of Animal Husbandry and Dairy Science RCSM college of Agriculture, Kolhapur, by using 9-point Hedonic scale (1disliked extremely; 9- liked extremely). as described by (Hue, 1993). Spreadability was assessed by the panelists using a piece of bread slice to spread the product at uniform experimental temperature $5 \pm 1{ }^{\circ} \mathrm{C}$.

\section{Physico-chemical properties}

The spread was analyzed for total solid, free fatty acids (FFA) content (Deeth et al., 1975) and oxidative deterioration in terms of thiobarbituric acid (TBA) value (King 1962). The $\mathrm{pH}$ of the spread was measured by $\mathrm{pH}$ 
meter (Lab India Instruments Pvt. Ltd., Mumbai). To estimate the wheying off and oiling off or free oil in the product, five slices of spread $(3 \mathrm{~mm}$ thick and $1.5 \mathrm{~cm}$ diameter each) were cut and placed on set (5 nos.) of moisture free, tared Whatman no.1 (2) filterpapers. These filter circles together with (5 no.) the sample slices were then weighed, held for $48 \mathrm{~h}$ at $20 \pm 1{ }^{\circ} \mathrm{C}$ and then transferred to refrigerator for $30 \mathrm{~min}$. The slices were then separated from the filter paper and the spread sticking to the paper was scraped off and the filter-paper weighed to get the weight gain from the sample. Thereafter, the filter papers were dried in an oven at $100 \pm 2{ }^{\circ} \mathrm{C}$ for $3 \mathrm{~h}$, cooled in desiccator and weighed again to determine the weight of the absorbed oil.

The amount of oil absorbed after deducting the total soluble solids in the product was taken as oiling off from spread at $20{ }^{\circ} \mathrm{C}$ and then the moisture absorbed was taken as wheying off (deMan and Wood, 1958).

\section{Microbiological quality}

For microbiological examination, samples were first tempered in a water-bath at $35 \pm 1$ ${ }^{\circ} \mathrm{C}$ for 5-7 min. Eleven grams of the sample was dispersed in previously autoclaved $99 \mathrm{ml}$ buffer peptone water (BPW) (Himedia, Mumbai). This represented the first dilution (1:10), subsequent dilutions being prepared by transferring $1 \mathrm{ml}$ of a particular dilution to 9 $\mathrm{ml}$ of BPW. The diluted sample was examined for yeast and mould counts, standard plate count (SPC), and coliform count (CC) (Robert, 1992).

\section{Statistical analysis}

The Data generated during the course of investigation were analyzed using factorial completely randomized design (FCRD) technique with five replications (Snedecor and Cochran, 1967).

\section{Results and Discussion}

\section{Changes in colour and appearance}

The data indicated that as the storage period progressed the scores for colour and appearance went decreasing significantly $(p<0.05)$. Figure 1 indicates that there was a very gradual decrease in the colour and appearance scores for 2 samples up to the end of storage period of 60 days.

The rate of decline was nearly similar in the all samples during the first 40 days, it was higher in strawberry spread, and the colour of freshly processed strawberry spread changes relatively rapidly from a bright to a dull red, which then makes its appearance generally less acceptable for consumers. The least decrease in colour and appearance score was observed for the preservative sample.

If score of 7 (like moderately) is taken as minimum for an acceptable product, all spreads remained acceptable during storage from colour point of view. It may however, be noted that surface discoloration become evident towards the end of storage. The main factor that affect the final anthocyanin concentration (Table 1).

The temperature during storage of spreads has a major impact on colour and pigment stability Kadivec et al., (2016). The changes in colour and appearance score of the samples during storage may be attributed to the addition of preservative and also rise in yeast and mold count that might have contributed to the surface discoloration of spread. Similar surface discoloration of low fat dairy spreads due to mound growth was also reported by Kharb (2007) and Babubhai (1999).

\section{Changes in body and texture}

The body and texture score of fresh sample ranged from 8.50 to 8.12 . The body and 
texture scores remain more or less unchanged for 40, 40and 80 days of storage in control spread, strawberry and preservative spreads, respectively. Thereafter, the score decreased to 7.32 after 60 days of storage in control spread, 7.12 on 60 days of storage in strawberry spread and 6.68 after 100 days of storage in preservative spread. These changes were statistically significant $(\mathrm{p}<0.05)$. A very slight decrease from 8.13 to 6.68 was observed in the body and texture scores for the preservative spread sample up to the end of storage period. Gradual decrease in the body and texture score was observed from initial days for the sample containing control spread. The strawberry spread shows faster rate of decline in scores after 40 days with respect to other samples. At the end of storage period the body and texture score for the samples control, strawberry and preservative spread was 7.32 , 7.16 and 6.68 respectively (Fig. 2).

\section{Changes in flavour}

Flavour scores of 3 spreads declined during storage, the decline being rapid and significant for the control spread. It may be seen that initial average score of the samples ranged from 7.42 to 8.33. It is evident from the Fig. 3 that there was a slight decreased in flavour scores in all the samples up to the end ofthe storage period. Control samples showed decline in flavour scores after 20 days, at the end of 60 days it decreases from $7.42 \pm 0.01$ to $6.75 \pm 0.06$.

The maximum decrease in flavour score was observed for the control sample as compared to the samples containing strawberry and preservative at the end of 60 days of storage.

The rate of flavour deterioration was slower during the initial period of storage but it increased appreciably towards the end of storage. The decrease in flavour scores may be attributed to loss of freshness.
It could be observed that the flavour score changes were significantly affected $(\mathrm{P}<0.05)$ storage day's increases. The changes in flavor scores may be attributed to the corresponding increase in the FFA content of all 3 samples of spread. The higher FFA content might have resulted from the hydrolysis of fat leading to development of slightly rancid off-flavour in the product. Spurgeon et al., (1973) reported that decline in the flavour score a butter flavored spread was considered to be due to reduction in diacetyl content of the spread during storage. Development of rancid flavour as a result of lipid hydrolysis was notice by Prajapati (1988) during six weeks storage of butter-flavored spread. Similar findings observed by Devdhara et al., (1991); Reddy et al.,(2001); Deshmukh et al.,(2003) and Kharb (2007). Patel (1982) observed development of fruity flavour in low calorie soy spread with progress in period of storage.

\section{Changes in spreadability}

The result pertaining to changes in spreadability behavior of the all 3 spread during storage period is presented in Fig.4. Spreadability score of the control spread from the initial 8.13 to 7.21 after 60 days storage and that of strawberry spread from 8.38 to 7.29 on 60 days of storage, and preservative spread 8.20 to 6.65 on 100 days. The spreadability score of the preservative spread (8.20) remained unchanged for up to 20 days. Thereafter, a slight but significant decrease was noticed during the rest of the storage period. A sharp decrease was noticed in spreadability score of strawberry spread initially up to 20 days thereafter gradual slowed a decline up to 40 days followed by sharp decline up to 60 days. The changes in spreadability scores of the product storage may be attributed to the changes in overall consistency of the product presumably due to protein degradation and /or decreased water holding by the non-fat fraction resulting in increased softening of the spread particularly 
such as protein is highly significant to crosslink and form interconnected molecular network in water suitable for spreading Chronakis and kasapis (1995). Spreadability assessment can be also made using instrumental methods involving mostly large deformations which break down the products' structure like extrusion, compression etc. Wright et al.,(2001) and small deformations Brunello et al., (2003).

\section{Changes in overall acceptability}

The fresh samples were highly acceptable, scores being 7.87, 8.43, and 8.06, respectively for Control spread, strawberry spread and Preservative added Spread. The scores however decreased significantly during storage. The rate of decrease in samples without preservative was higher as compared to that in the spread with preservative implying a significant. The decreasing score with advancing storage period may be attributed to the decline in flavour of the spread as also to softening of the product. Overall acceptability of the yoghurt fortified with strawberry had decreased significantly due to flavour and acidity related changes during storage was reported by (Narayan and Gupta. 2018) (Fig. 5).

\section{Changes in total solid (\%)}

The total solid (TS) content of the samples at different period of storage is presented in graphically in Figure 6. Initial average values of TS of the control LFS 0,20,40 and 60 days were found to be $60.38 \pm 0.08,60.23 \pm 0.05$, $60.18 \pm 0.03,59.39 \pm 0.02$ per cent respectively, the TS value of strawberry spread $0,20,40$ and 60 days $60.58 \pm 0.03,60.42 \pm 0.01,60.35 \pm 0.03$, $60.12 \pm 0.02$ respectively and the TS value of preservative spread $0,20,40,60,80$, and 100 days were $60.48 \pm 0.05,60.30 \pm 0.09$, $60.11 \pm 0.01, \quad 60.03 \pm 0.01, \quad 60.23 \pm 0.05$ and $59.87 \pm 0.01$, respectively.
The effect of TS was found to be significant among the treatments, storage periods as well as for the interaction between the treatment and storage periods at 5\% level of significance. Singh et al., (2014) were also prepared milk beverage from $3.5 \%$ vegetable oil and 15\% mango pulp had fat $(2.9 \%)$ and total solid (18.73\%). These finding are on somewhat similar line of present study.

\section{Changes in $\mathbf{p H}$}

The $\mathrm{pH}$ of $\mathrm{T}_{1}, \mathrm{~T}_{2}$ and $\mathrm{T}_{3}$ LFS spread stored at $5^{\circ} \mathrm{C}$ are presented in fig.7. It is evident from the table 3 at the end of 60 day of storage the initial $\mathrm{pH}$ of 5.32 decreased slightly but significantly to 5.11in the product, also end of 60 days of storage the initial $\mathrm{pH}$ of 5.31 decreased significantly 5.15 in the $\mathrm{T}_{2}$ sample and in the synthetic preservative added low-fat spread the initial $\mathrm{pH}$ of 5.29decreased significantly to 5.05 after 100 days of storage in the product preserved with potassium sorbate and BHA.

\section{Free fatty acids (FFA) content}

Fat containing dairy product usually undergoes lipolysis, an important change which affects the acceptability of the product. Lipolysis under controlled condition within limit is desirable, but it has a detrimental effect on the keeping quality beyond certain limit. The lipolysis was measured in terms of FFA content. The changes in free fatty acids content of LFS, strawberry LFS, and preservative LFS are depicted in Table 3 and Fig.8. A steady increase was observed in the free fatty acid content of control sample from an initial value of 23.63 to 32.50 after 60 days of storage. The FFA content of samples containing strawberry and preservative also showed gradual increased up to 60 days and 100 days respectively. However, the samples containing preservative showed the least FFA content amongst the samples under investigation. The ANOVA revealed that the 
type of spread, storage days and their interactions significantly $(\mathrm{P}<0.05)$ affected in FFA content of all samples during storage An increase in FFA in a 'low-calorie butter' during storage due to the continuous lipolytic breakdown as a result of the growth of yeasts and moulds has been reported in previous study Ibrahim et al., (1994).

Patel and Gupta (1989) also reported increases in the FFA content of a low-fat soya spread with progressive storage.

Similar trends of rise in FFA content of stored spreads were also observed by other workers (Devdhara et al., 1991); Deshmukh et al., (2003); John and Tyagi 2003) the increase in the free fatty acid content during storage may be due to the hydrolytic breakdown of the fat. The increase in FFA content during storage has also been reported by Deshpande (1998), Kharb (2007) Patange et al., (2013) and Adbeledaien et al.,(2014) in different type of spread (Table 2).

\section{Changes in peroxide value}

Beside liberation of FFA, lipids undergo oxidative deterioration during storage, the extent of which expressed as peroxide value. From the data in Table 3and fig. 9, it revealed that the peroxide value was increased gradually in all samples of LFS during storage. The increase in peroxide value was observed higher in control LFS than strawberry LFS and preservative LFS.

The peroxide value increase from $0.32 \pm 0.04$ to $2.30 \pm 0.01$ Milli equivalent $/ \mathrm{kg}$ fat in control LFS (60 days), $0.323 \pm 0.03$ to $2.20 \pm 0.01$ Milli equivalent/ $\mathrm{kg}$ in strawberry LFS (60 days) and $0.34 \pm 0.04$ to $1.05 \pm 0.05$ Milli equivalent/ $\mathrm{kg}$ fat in preservative LFS (100 days). The increased in peroxide value in fruit LFS during storage was also reported by Ofosu et al., (2011) and Adbeldaien et al., (2014).

\section{Changes in TBA value (OD)}

Thiobarbutric acid (TBA) reaction was used to monitor oxidative deterioration in the spread during storage. The changes in TBA number of the LFS, Strawberry LFS, and preservative LFS during storage are presented in fig. 10.

The initial TBA number of the LFS, strawberry LFS, and preservative LFS to be $0.170,0.171$ and 0.175 respectively, which increased to $0.240,0.202,0.201$ respectively at the end of respective storage period when stored at $5^{\circ} \mathrm{C}$.further the TBA value remained almost unchanged during the first 20 days of the storage period, but tended to increase later.

The increase was linear and statistically significant $(\mathrm{P}<0.05)$ towards the end of storage period. Moreover, the TBA value usually higher for control LFS than for Strawberry LFS and preservative LFS.

The difference being significant $(\mathrm{P}<0.05)$. The flavour score had a negative correlation with TBA value.it appeared that the decrease in the flavour score was substantially accounted for by the oxidative deterioration taking place in the product during storage. The slight protective effect of the preservative on the spread against oxidation was also reported by Titarenko et al., (1985) who used sorbic acid in low fat butter. The findings of Reddy et al., (2001) corroborated the present results.

\section{Changes in oiling off $(\%)$}

The results on changes in oiling off spread during storage are presented in fig 11. Perusal of the data revels that with progress in storage. Oiling off of the spread increased gradually, in the 3 spreads, the increase was significant $(\mathrm{P}<0.05)$. This small increase implied that the spread had good emulsion stability during storage (Table 4-6). 
Table.1 Changes in Sensory score of low fat spread added with $\mathrm{T}_{1}, \mathrm{~T}_{2}$ and $\mathrm{T}_{3}$ during storage at $5^{\circ} \mathrm{C}$

\begin{tabular}{|c|c|c|c|c|c|c|c|}
\hline \multirow{2}{*}{$\begin{array}{l}\text { Sensory } \\
\text { attributes }\end{array}$} & \multirow[t]{2}{*}{ Treatment } & \multicolumn{6}{|c|}{ Storage periods(days) } \\
\hline & & 0 & 20 & 40 & 60 & 80 & 100 \\
\hline \multirow{3}{*}{$\begin{array}{l}\text { Colour and } \\
\text { Appearance }\end{array}$} & $\mathrm{T}_{1}($ Control $)$ & $7.80 \pm 0.01$ & $7.71 \pm 0.02$ & $7.58 \pm 0.05$ & $7.22 \pm 0.01$ & -- & -- \\
\hline & $\mathrm{T}_{2}(\mathrm{SS})$ & $8.50 \pm 0.01$ & $8.25 \pm 0.01$ & $7.81 \pm 0.07$ & $7.33 \pm 0.08$ & -- & -- \\
\hline & $\mathrm{T}_{3}$ (Preservative) & $7.78 \pm 0.05$ & $7.65 \pm 0.01$ & $7.48 \pm 0.05$ & $7.29 \pm 0.07$ & $7.06 \pm 0.03$ & $6.85 \pm 0.01$ \\
\hline \multirow{3}{*}{$\begin{array}{l}\text { Body and } \\
\text { Texture }\end{array}$} & $\mathrm{T}_{1}($ Control $)$ & $8.12 \pm 0.01$ & $7.86 \pm 0.06$ & $7.63 \pm 0.06$ & $7.32 \pm 0.05$ & -- & -- \\
\hline & $\mathrm{T}_{2}(\mathrm{SS})$ & $8.50 \pm 0.01$ & $8.20 \pm 0.04$ & $7.48 \pm 0.02$ & $7.16 \pm 0.08$ & -- & -- \\
\hline & $\mathrm{T}_{3}$ (Preservative) & $8.13 \pm 0.01$ & $7.88 \pm 0.01$ & $7.66 \pm 0.03$ & $7.31 \pm 0.02$ & $7.06 \pm 0.01$ & $6.68 \pm 0.09$ \\
\hline \multirow[t]{3}{*}{ Flavour } & $\mathrm{T}_{1}($ Control $)$ & $7.42 \pm 0.01$ & $7.23 \pm 0.04$ & $7.08 \pm 0.05$ & $6.75 \pm 0.06$ & -- & -- \\
\hline & $\mathrm{T}_{2}(\mathrm{SS})$ & $8.33 \pm 0.06$ & $8.07 \pm 0.04$ & $7.88 \pm 0.06$ & $7.13 \pm 0.01$ & -- & -- \\
\hline & $\mathrm{T}_{3}($ Preservative $)$ & $8.12 \pm 0.01$ & $7.52 \pm 0.05$ & $7.80 \pm 0.01$ & $7.45 \pm 0.01$ & $7.38 \pm 0.02$ & $6.94 \pm 0.09$ \\
\hline \multirow[t]{3}{*}{ Spreadability } & $\mathrm{T}_{1}($ Control $)$ & $8.13 \pm 0.06$ & $7.85 \pm 0.02$ & $7.60 \pm 0.01$ & $7.21 \pm 0.08$ & -- & -- \\
\hline & $\mathrm{T}_{2}(\mathrm{SS})$ & $8.38 \pm 0.03$ & $8.11 \pm 0.01$ & $7.70 \pm 0.04$ & $7.29 \pm 0.07$ & -- & -- \\
\hline & $\mathrm{T}_{3}$ (Preservative) & $8.20 \pm 0.03$ & $7.94 \pm 0.04$ & $7.63 \pm 0.03$ & $7.25 \pm 0.03$ & $7.18 \pm 0.01$ & $6.65 \pm 0.02$ \\
\hline \multirow{3}{*}{$\begin{array}{l}\text { Overall } \\
\text { acceptability }\end{array}$} & $\mathrm{T}_{1}$ (Control) & $7.87 \pm 0.05$ & $7.66 \pm 0.01$ & $7.47 \pm 0.05$ & $7.13 \pm 0.04$ & -- & -- \\
\hline & $\mathrm{T}_{2}(\mathrm{SS})$ & $8.43 \pm 0.07$ & $8.16 \pm 0.06$ & $7.72 \pm 0.05$ & $7.23 \pm 0.09$ & -- & -- \\
\hline & $\mathrm{T}_{3}$ (Preservative) & $8.06 \pm 0.05$ & $7.75 \pm 0.07$ & $7.65 \pm 0.03$ & $7.32 \pm 0.03$ & $7.17 \pm 0.07$ & $6.78 \pm 0.05$ \\
\hline
\end{tabular}

*means of three replicates

Table.2 ANOVA for sensory score of the stored low fat spread

\begin{tabular}{|c|c|c|c|c|c|c|}
\hline $\begin{array}{l}\text { Sensory } \\
\text { attributes }\end{array}$ & Source of variation & DF & MSS & Fcal & SEm & $\begin{array}{l}\text { CD } \\
(p<0.05)\end{array}$ \\
\hline \multirow{4}{*}{$\begin{array}{l}\text { Colour and } \\
\text { Appearance }\end{array}$} & Between treatment & 2 & 28.5858 & 12164.1868 & 0.011 & 0.03 \\
\hline & Between Storage & 5 & 70.06704 & 29815.7617 & 0.016 & 0.04 \\
\hline & Intercept & 10 & 13.8395 & 5889.1881 & 0.027 & 0.08 \\
\hline & Error & 36 & 0.00235 & -- & -- & -- \\
\hline \multirow{4}{*}{$\begin{array}{ll}\text { Body } & \text { and } \\
\text { Texture } & \end{array}$} & Between treatment & 2 & 30.8027 & 14265.4039 & 0.010953 & 0.031414 \\
\hline & Between Storage & 5 & 73.131 & 33868.728 & 0.015489 & 0.044426 \\
\hline & Intercept & 10 & 12.8019 & 5928.85575 & 0.026828 & 0.076948 \\
\hline & Error & 36 & 0.002159 & -- & -- & -- \\
\hline \multirow[t]{4}{*}{ Flavour } & Between treatment & 2 & 39.9086 & 14913.9682 & 0.012 & 0.03 \\
\hline & Between Storage & 5 & 65.05461 & 24311.0689 & 0.017 & 0.04 \\
\hline & Intercept & 10 & 12.97104741 & 4847.31183 & 0.029 & 0.08 \\
\hline & Error & 36 & 0.002675 & -- & -- & -- \\
\hline \multirow[t]{4}{*}{ Spreadability } & Between treatment & 2 & 31.42228 & 9421.8186 & 0.01 & 0.03 \\
\hline & Between Storage & 5 & 72.785758 & 21824.4517 & 0.019 & 0.05 \\
\hline & Intercept & 10 & 12.906060 & 3869.81882 & 0.03 & 0.09 \\
\hline & Error & 36 & 0.003335056 & -- & -- & -- \\
\hline \multirow{4}{*}{$\begin{array}{l}\text { Overall } \\
\text { acceptability }\end{array}$} & Between treatment & 2 & 32.4470 & 40500.8704 & 0.006 & 0.01 \\
\hline & Between Storage & 5 & 70.19208 & 87614.7071 & 0.009 & 0.02 \\
\hline & Intercept & 10 & 13.1000 & 16351.6422 & 0.016 & 0.04 \\
\hline & Error & 36 & 0.000801145 & & & \\
\hline
\end{tabular}


Table.3 Physico-chemical changes in low fat spread added with $\mathrm{T}_{1}, \mathrm{~T}_{2}$ and $\mathrm{T}_{3}$ during storage at $5^{\circ} \mathrm{C}$

\begin{tabular}{|c|c|c|c|c|c|c|c|}
\hline \multirow{2}{*}{$\begin{array}{l}\text { Physico- } \\
\text { chemical } \\
\text { attributes }\end{array}$} & \multirow[t]{2}{*}{ Treatment } & \multicolumn{6}{|c|}{ Storage periods(days) } \\
\hline & & 0 & 20 & 40 & 60 & 80 & 100 \\
\hline \multirow[t]{3}{*}{ Total solid } & $\mathrm{T}_{1}($ Control $)$ & $60.38 \pm 0.08$ & $60.23 \pm 0.05$ & $60.18 \pm 0.03$ & $59.39 \pm 0.02$ & -- & -- \\
\hline & $\mathrm{T}_{2}(\mathrm{SS})$ & $60.58 \pm 0.03$ & $60.42 \pm 0.01$ & $60.35 \pm 0.03$ & $60.12 \pm 0.02$ & -- & -- \\
\hline & $\mathrm{T}_{3}$ (Preservative) & $60.48 \pm 0.05$ & $60.30 \pm 0.09$ & $60.11 \pm 0.01$ & $60.03 \pm 0.01$ & $60.23 \pm 0.05$ & $59.87 \pm 0.01$ \\
\hline \multirow{3}{*}{ pH } & $\mathrm{T}_{1}($ Control $)$ & $5.32 \pm 0.02$ & $5.26 \pm 0.02$ & $5.21 \pm 0.05$ & $5.11 \pm 0.03$ & -- & -- \\
\hline & $\mathrm{T}_{2}(\mathrm{SS})$ & $5.31 \pm 0.02$ & $5.25 \pm 0.02$ & $5.22 \pm 0.01$ & $5.15 \pm 0.03$ & -- & -- \\
\hline & $\mathrm{T}_{3}$ (Preservative) & $5.29 \pm 0.03$ & $5.28 \pm 0.01$ & $5.25 \pm 0.02$ & $5.17 \pm 0.01$ & $5.11 \pm 0.03$ & $5.05 \pm 0.02$ \\
\hline \multirow{3}{*}{$\begin{array}{l}\text { Free Fatty } \\
\text { Acids(FFA) } \\
\text { equiv/g }\end{array}$} & $\mathrm{T}_{1}($ Control $)$ & $23.63 \pm 0.01$ & $26.07 \pm 0.07$ & $29.60 \pm 0.04$ & $32.50 \pm 0.04$ & -- & -- \\
\hline & $\mathrm{T}_{2}(\mathrm{SS})$ & $22.57 \pm 0.05$ & $24.37 \pm 0.01$ & $26.42 \pm 0.03$ & $28.38 \pm 0.01$ & -- & -- \\
\hline & $\mathrm{T}_{3}$ (Preservative) & $23.46 \pm 0.04$ & $24.42 \pm 0.01$ & $26.33 \pm 0.01$ & $27.65 \pm 0.06$ & $29.32 \pm 0.04$ & $30.91 \pm 0.04$ \\
\hline \multirow{3}{*}{$\begin{array}{l}\text { PV meq. of } \\
\text { peroxide/kg } \\
\text { of fat }\end{array}$} & $\mathrm{T}_{1}($ Control $)$ & $0.32 \pm 0.04$ & $0.48 \pm 0.06$ & $0.97 \pm 0.04$ & $2.30 \pm 0.01$ & -- & -- \\
\hline & $\mathrm{T}_{2}(\mathrm{SS})$ & $0.32 \pm 0.03$ & $0.44 \pm 0.02$ & $1.66 \pm 0.02$ & $2.20 \pm 0.01$ & -- & -- \\
\hline & $\mathrm{T}_{3}$ (Preservative) & $0.30 \pm 0.04$ & $0.38 \pm 0.05$ & $0.72 \pm 0.02$ & $1.65 \pm 0.04$ & $2.05 \pm 0.05$ & $1.05 \pm 0.05$ \\
\hline \multirow[t]{3}{*}{ TBA } & $\mathrm{T}_{1}($ Control $)$ & $0.17 \pm 0.04$ & $0.18 \pm 0.03$ & $0.22 \pm 0.01$ & $0.24 \pm 0.03$ & -- & -- \\
\hline & $\mathrm{T}_{2}(\mathrm{SS})$ & $0.17 \pm 0.01$ & $0.18 \pm 0.07$ & $0.19 \pm 0.04$ & $0.20 \pm 0.02$ & -- & -- \\
\hline & $\mathrm{T}_{3}$ (Preservative) & $0.17 \pm 0.05$ & $0.18 \pm 0.02$ & $0.18 \pm 0.01$ & $0.19 \pm 0.02$ & $0.20 \pm 0.01$ & $0.21 \pm 0.04$ \\
\hline \multirow[t]{3}{*}{ Oiling off } & $\mathrm{T}_{1}($ Control $)$ & $3.74 \pm 0.05$ & $3.81 \pm 0.06$ & $3.87 \pm 0.03$ & $3.93 \pm 0.06$ & -- & -- \\
\hline & $\mathrm{T}_{2}(\mathrm{SS})$ & $3.73 \pm 0.02$ & $3.77 \pm 0.03$ & $3.85 \pm 0.02$ & $3.88 \pm 0.05$ & -- & -- \\
\hline & $\mathrm{T}_{3}$ (Preservative) & $3.70 \pm 0.02$ & $3.75 \pm 0.02$ & $3.79 \pm 0.02$ & $3.84 \pm 0.07$ & $3.97 \pm 0.02$ & $4.04 \pm 0.02$ \\
\hline \multirow[t]{3}{*}{ Wheying off } & $\mathrm{T}_{1}($ Control $)$ & $7.60 \pm 0.02$ & $7.72 \pm 0.07$ & $7.82 \pm 0.08$ & $7.86 \pm 0.04$ & -- & -- \\
\hline & $\mathrm{T}_{2}(\mathrm{SS})$ & $7.56 \pm 0.02$ & $7.62 \pm 0.05$ & $7.78 \pm 0.01$ & $7.93 \pm 0.02$ & -- & -- \\
\hline & $\mathrm{T}_{3}$ (Preservative) & $7.58 \pm 0.03$ & $7.51 \pm 0.08$ & $7.63 \pm 0.02$ & $7.76 \pm 0.02$ & $7.76 \pm 0.03$ & $7.83 \pm 0.03$ \\
\hline
\end{tabular}


Table.4 ANOVA for physico-chemical changes in LFS during storage

\begin{tabular}{|c|c|c|c|c|c|c|}
\hline $\begin{array}{l}\text { Physico- } \\
\text { chemical } \\
\text { attributes }\end{array}$ & Source of variation & DF & MSS & Fcal & SEm & $\begin{array}{l}\text { CD } \\
(\mathbf{p}<0.05)\end{array}$ \\
\hline \multirow{4}{*}{ Total solid } & Between treatment & 2 & 2408.2445 & 82057.28 & 0.04 & 0.11 \\
\hline & Between Storage & 5 & 3878.41452 & 132151.1 & 0.05 & 0.16 \\
\hline & Intercept & 10 & 960.863700 & 32739.97 & 0.09 & 0.28 \\
\hline & Error & 36 & 0.0293483 & & & \\
\hline \multirow{4}{*}{$\mathbf{P h}$} & Between treatment & 2 & 17.436535 & 6170.202 & 0.01 & 0.03 \\
\hline & Between Storage & 5 & 30.163932 & 10674 & 0.01 & 0.05 \\
\hline & Intercept & 10 & 6.8298285 & 2416.846 & 0.03 & 0.08 \\
\hline & Error & 36 & 0.0028259 & & & \\
\hline \multirow{4}{*}{$\begin{array}{l}\text { Free Fatty } \\
\text { Acids(FFA) } \\
\text { equiv/g }\end{array}$} & Between treatment & 2 & 522.85061 & 13331.95 & 0.04 & 0.13 \\
\hline & Between Storage & 5 & 674.88516 & $17208 . .6$ & 0.06 & 0.18 \\
\hline & Intercept & 10 & 265.37788 & 6766.762 & 0.11 & 0.32 \\
\hline & Error & 36 & 0.0392178 & & & \\
\hline \multirow{4}{*}{$\begin{array}{ll}\text { PV meq. } & \text { of } \\
\text { peroxide/kg } & \text { of } \\
\text { fat } & \end{array}$} & Between treatment & 2 & 0.6799880 & 690.8630 & 0.007 & 0.21 \\
\hline & Between Storage & 5 & 3.1529866 & 3203.449 & 0.01 & 0.02 \\
\hline & Intercept & 10 & 1.6134706 & 1639.293 & 0.01 & 0.05 \\
\hline & Error & 36 & 0.0009842 & & & \\
\hline \multirow[t]{4}{*}{ TBA } & Between treatment & 2 & 0.0219361 & 11148.24 & 0.003 & 0.0009 \\
\hline & Between Storage & 5 & 0.0364995 & 18549.57 & 0.0004 & 0.0013 \\
\hline & Intercept & 10 & 0.0129030 & 6557.531 & 0.0008 & 0.0023 \\
\hline & Error & 36 & 1.96768 & & & \\
\hline \multirow[t]{4}{*}{ Oiling off } & Between treatment & 2 & 10.147299 & 27069.03 & 0.004 & 0.01 \\
\hline & Between Storage & 5 & 14.657192 & 39099.66 & 0.006 & 0.01 \\
\hline & Intercept & 10 & 4.397028 & 11729.55 & 0.011 & 0.03 \\
\hline & Error & 36 & 0.0003748 & & & \\
\hline \multirow[t]{4}{*}{ Wheying off } & Between treatment & 2 & 38.090315 & 40206.2 & 0.007 & 0.02 \\
\hline & Between Storage & 5 & 62.490733 & 65962.20 & 0.01 & 0.02 \\
\hline & Intercept & 10 & 16.705563 & 17633.5 & 0.01 & 0.05 \\
\hline & Error & 36 & 0.0009473 & & & \\
\hline
\end{tabular}


Table.5 Microbial changes in low fat spread added with $\mathrm{T}_{1}, \mathrm{~T}_{2}$ and $\mathrm{T}_{3}$ during storage at $5^{\circ} \mathrm{C}$

\begin{tabular}{|c|c|c|c|c|c|c|c|}
\hline \multirow{2}{*}{$\begin{array}{l}\text { Microbial } \\
\text { analysis }\end{array}$} & \multirow[t]{2}{*}{ Treatment } & \multicolumn{6}{|c|}{ Storage periods(days) } \\
\hline & & 0 & 20 & 40 & 60 & 80 & 100 \\
\hline \multirow[t]{3}{*}{ SPC $(\log / g)$} & $\mathrm{T}_{1}$ (Control) & $2.0 \pm 0.02$ & $3.48 \pm 0.01$ & $4.51 \pm 0.01$ & $5.52 \pm 0.01$ & -- & -- \\
\hline & $\mathrm{T}_{2}(\mathrm{SS})$ & $1.32 \pm 0.03$ & $1.97 \pm 0.02$ & $4.08 \pm 0.06$ & $5.42 \pm 0.07$ & -- & -- \\
\hline & $\mathrm{T}_{3}($ Preservative $)$ & $1.12 \pm 0.01$ & $2.62 \pm 0.01$ & $3.48 \pm 0.03$ & $4.25 \pm 0.05$ & $5.20 \pm 0.02$ & $5.90 \pm 0.02$ \\
\hline \multirow[t]{3}{*}{ YMC (cfu/g) } & $\mathrm{T}_{1}($ Control $)$ & 0.00 & $22.00 \pm 0.02$ & $48.00 \pm 0.02$ & $91.17 \pm 0.03$ & -- & -- \\
\hline & $\mathrm{T}_{2}(\mathrm{SS})$ & 0.00 & $19.00 \pm 0.02$ & $38.30 \pm 0.01$ & $62.33 \pm 0.03$ & -- & -- \\
\hline & $\mathrm{T}_{3}$ (Preservative) & 0.00 & $6.00 \pm 0.02$ & $12.00 \pm 0.04$ & $22.00 \pm 0.02$ & $41.33 \pm 0.02$ & $61.33 \pm 0.04$ \\
\hline \multirow[t]{3}{*}{$\mathrm{CC}(\mathrm{cfu} / \mathrm{g})$} & $\mathrm{T}_{1}$ (Control) & NIL & NIL & NIL & NIL & NIL & NIL \\
\hline & $\mathrm{T}_{2}(\mathrm{SS})$ & NIL & NIL & NIL & NIL & NIL & NIL \\
\hline & $\mathrm{T}_{3}$ (Preservative) & NIL & NIL & NIL & NIL & NIL & NIL \\
\hline
\end{tabular}

Table.6 ANOVA for Microbial Analysis Changes in LFS during Storage

\begin{tabular}{|l|l|l|l|l|l|l|}
\hline $\begin{array}{l}\text { Microbial } \\
\text { analysis }\end{array}$ & Source of variation & DF & MSS & Fcal & SEm & $\begin{array}{l}\text { CD } \\
(\mathbf{p}<\mathbf{0 . 0 5})\end{array}$ \\
\hline SPC & Between treatment & 2 & 12.7162 & 2042.938 & 0.0185 & 0.053 \\
\cline { 2 - 7 } & Between Storage & 5 & 18.3638 & 2950.2590 & 0.0262 & 0.075 \\
\cline { 2 - 8 } & Intercept & 10 & 10.7545 & 1727.7752 & 0.0455 & 0.130 \\
\cline { 2 - 8 } & Error & 36 & 0.0062 & & & \\
\hline YMC & Between treatment & 2 & 216.4835 & 178.3116 & 0.2597 & 0.7448 \\
\cline { 2 - 8 } & Between Storage & 5 & 3651.0051 & 3007.2342 & 0.3672 & 1.0534 \\
\cline { 2 - 8 } & Intercept & 10 & 2026.5424 & 1669.2082 & 0.6361 & 1.8245 \\
\cline { 2 - 8 } & Error & 36 & 1.2140 & & & \\
\hline
\end{tabular}


Fig.1 Storage related changes occurs in colour and appearance of LFS

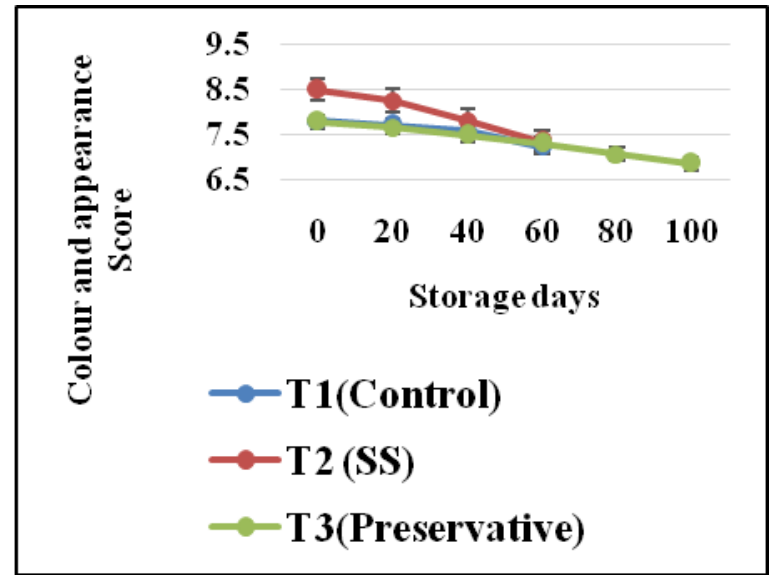

Fig.3 Storage related changes occurs in flavour of LFS

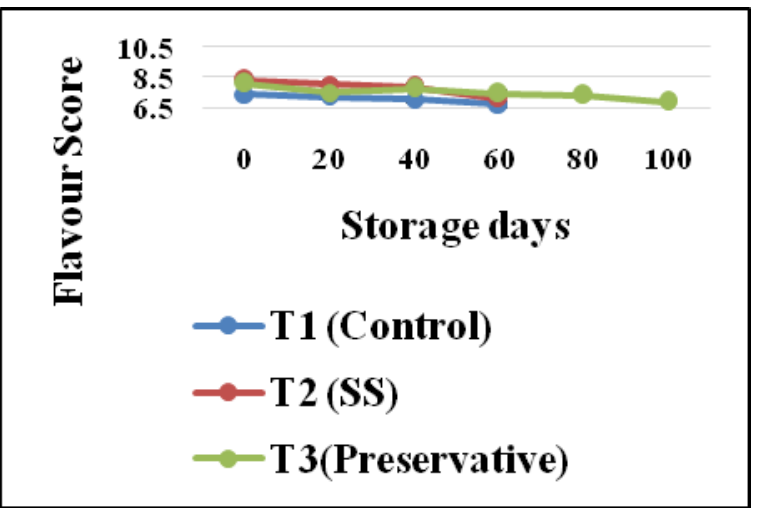

Fig.5 Storage related changes occurs in overall acceptability of LFS

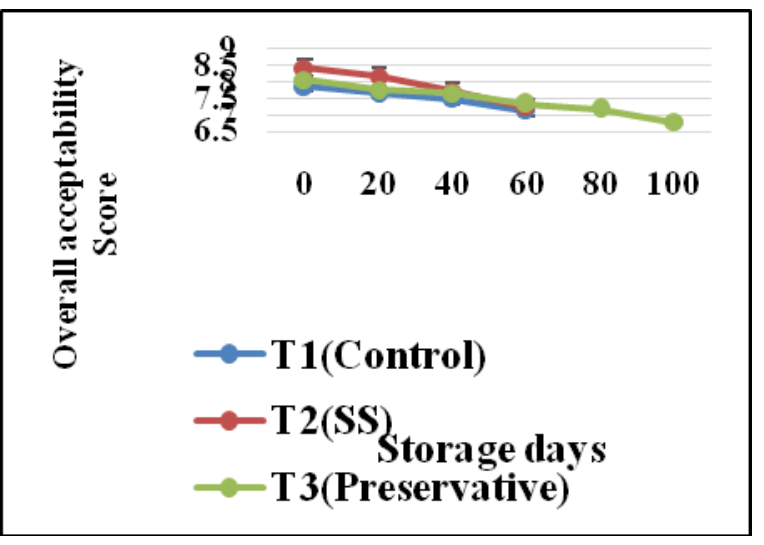

Fig.2 Storage related changes occurs in body and texture of LFS

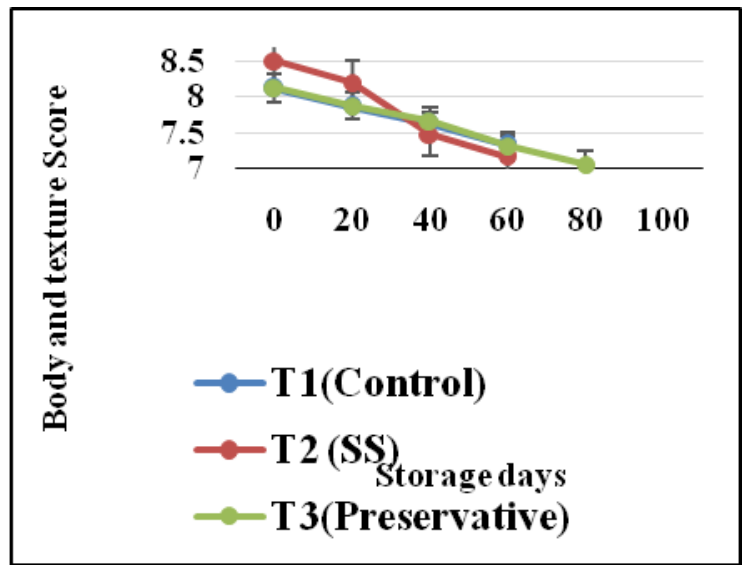

Fig.4 Storage related changes occurs in spreadability of LFS

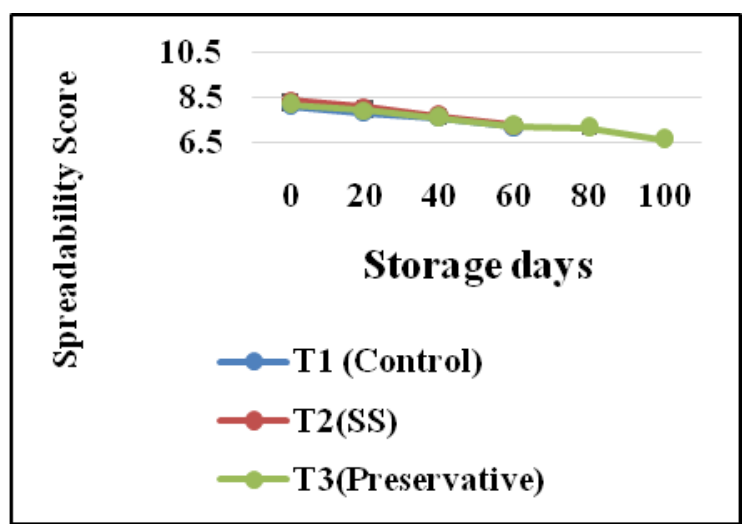

Fig.6 Storage related changes occurs in Total solid (\%) of LFS

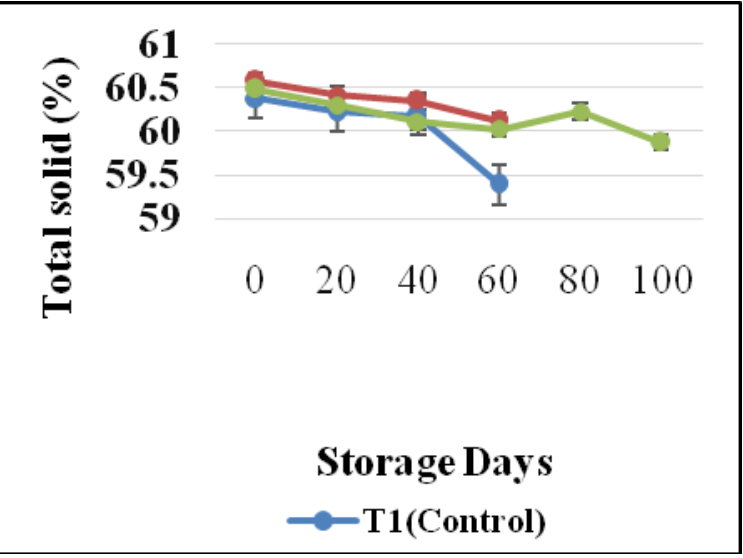


Fig.7 Storage related changes occurs in $\mathrm{pH}$ values of LFS

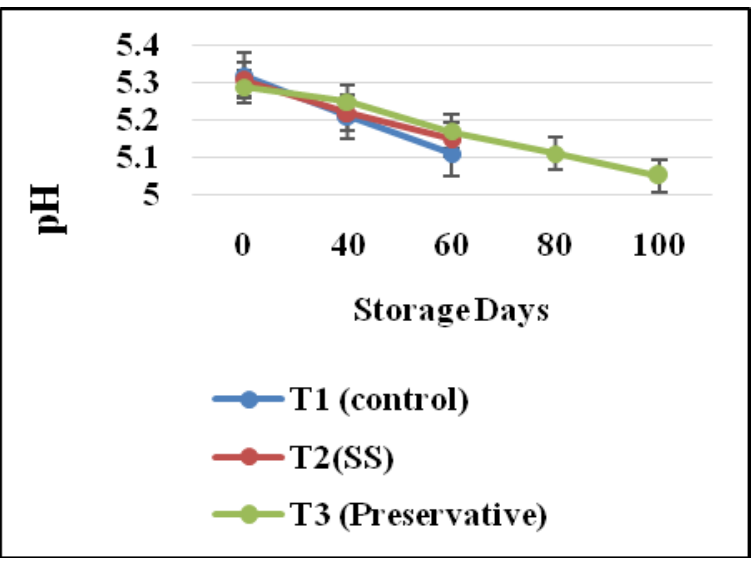

Fig.9 Storage related changes occurs in peroxide value (Milli equivalent/ $\mathrm{kg}$ fat) of

LFS

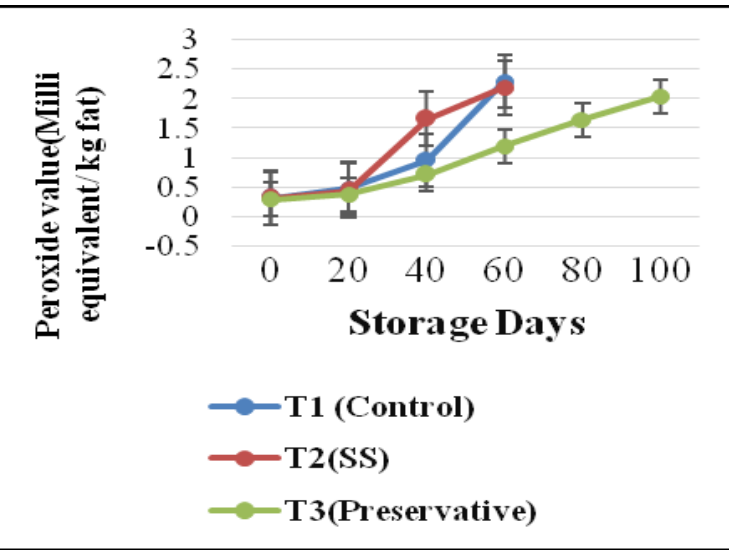

Fig.11 Storage related changes occurs in oiling off (\%) of LFS

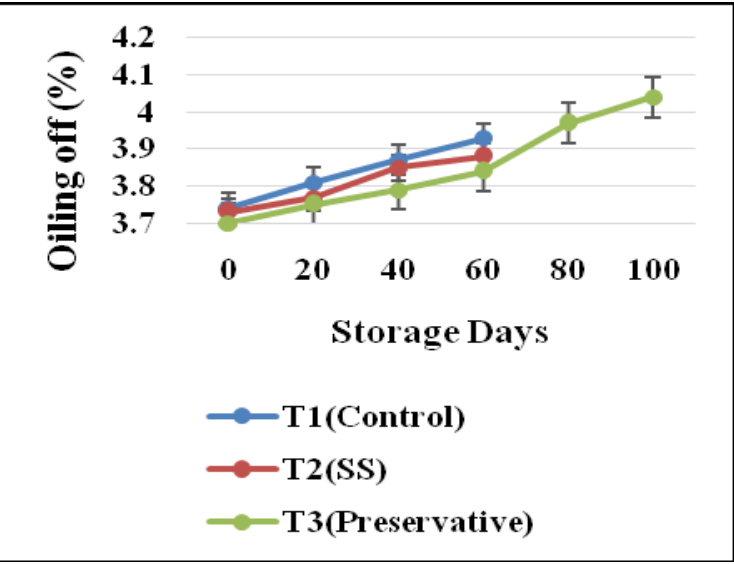

Fig.8 Storage related changes occurs in FFA(equiv/g)LFS

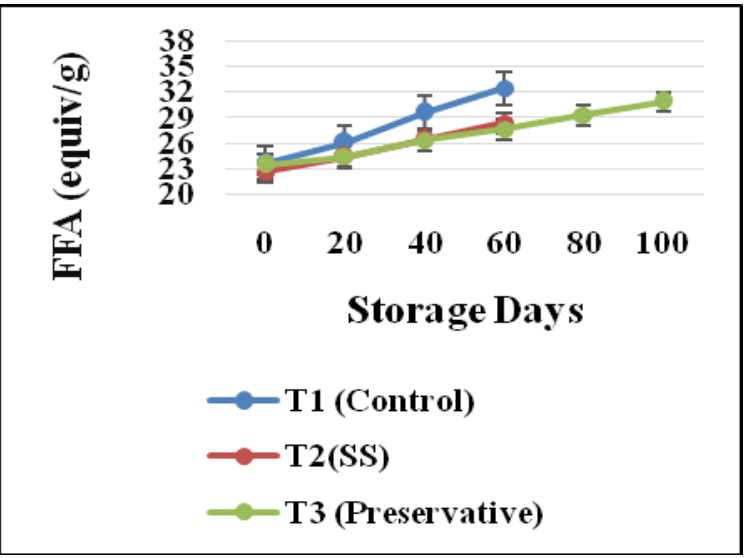

Fig.10 Storage related changes occurs in TBA (OD) value of LFS

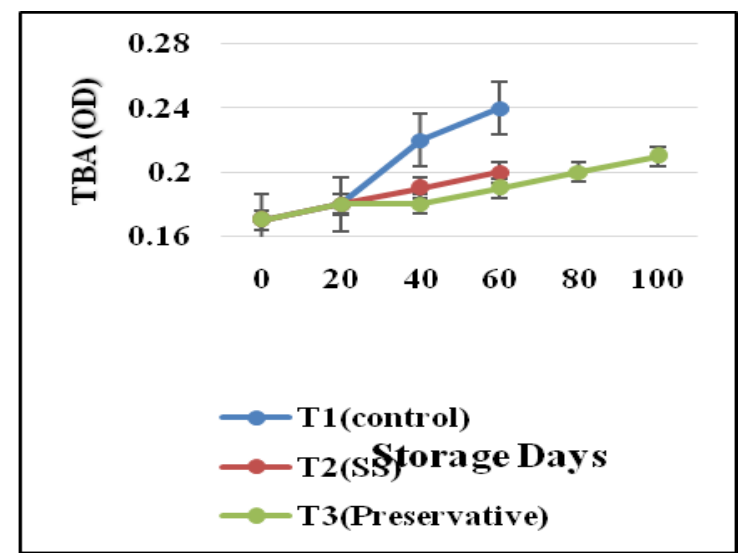

Fig.12 Storage related changes occurs in wheying off (\%) of LFS

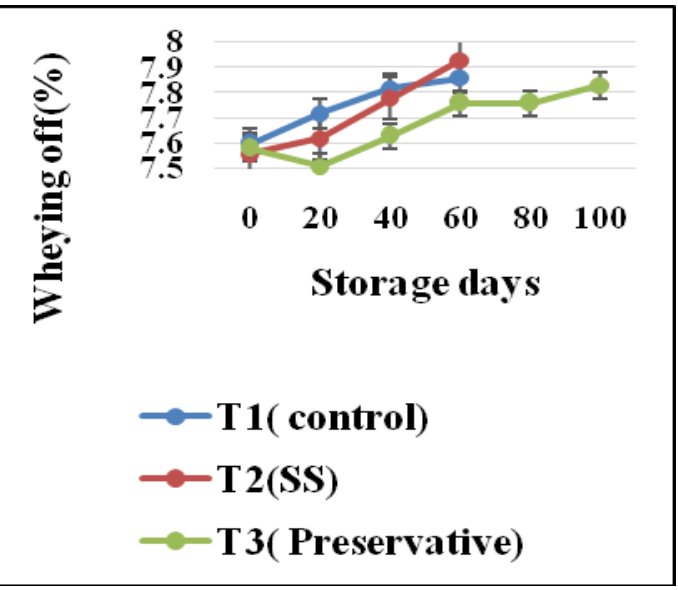


Fig.13 Storage related changes occurs in $\mathrm{SPC}(\mathrm{cfu} / \mathrm{g})$ of LFS

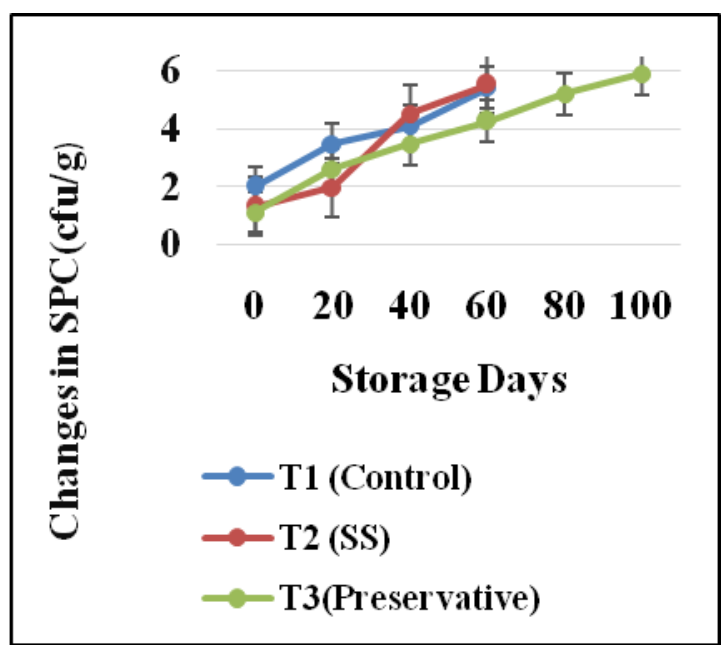

The oiling off recorded at the end of storage period for control LFS, strawberry LFS, preservative LFS were $3.93,3.88$ and 4.04 respectively. Verma et al., (1998) also reported a little change in oiling off in LFS during storage. Bhardwaj et al., (2017) also reported that there is increase in oiling off pomegranate peel extract cream based fat spread as the storage period increases due to compositional degradation of the spread leading to oil separation. Oil separation upon storage of spread containing maltodextrin was also observed by Reddy et al., (2017) (Fig. $11)$.

\section{Changes in Wheying off $(\%)$}

A slight but significant $(\mathrm{P}<0.05)$ increase in wheying off was noticed in the 3 spreads during storage. The increase in wheying off from 7.60 to 7.86 per cent in control LFS, 7.56 to 7.93 per cent in strawberry LFS and 7.58 to 7.83 in preservative LFS indicates a steady increase in the wheying off during storage. The increase in wheying off in preservative sample is lower than strawberry LFS, and control LFS (Fig. 12).

The findings are according of Verma et al., (1986) who reported increase in wheying off
Fig.14 Storage related changes occurs in YMC(cfu/g)of LFS

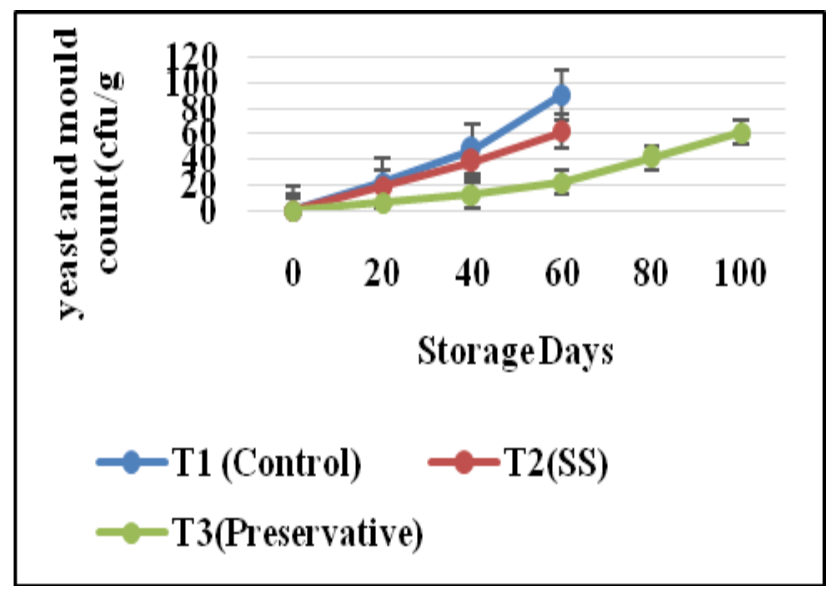

with increase in the storage period for a low fat spread. This may be attributed to increase softening of the product, attributable to the changed protein status, resulting in more free whey.

Bhardwaj et al., (2017) reported that as the storage period increases the wheying off increases due to slight destabilization of the emulsion started which may be due to degradation of the spread. Compare to the control sample wheying off was significantly lower similar observation was also recorded by Narayana and Gupta (2018) in stored yoghurt added with strawberry pulp and it may be because of water holding capacity of strawberry pulp.

\section{Changes in standard plate count $\left(\log _{10} \mathrm{CFU} / \mathrm{g}\right)$}

The results of the effect of storage period on standard plate count (SPC) for LFS, Strawberry LFS, Preservative LFS, from Table 3.it is revealed that as the storage period increased the SPC count also increased the mean SPC count of $\mathrm{T}_{1}(\mathrm{CS}), \mathrm{T}_{2}$ (SS), and $\mathrm{T}_{3}$ (PS) ranged from 2 to $5.52,1.32$ to $5.42,1.12$ to $5.90 \mathrm{cu} / \mathrm{ml}$ respectively over a storage period. In preservative LFS, SPC was lower as 
compared to other samples in all stages of storage period. It could be seen that the strawberry helped in a controlling the growth of microorganism. As it is reported that the strawberry contained some of phenolic and antioxidant substances which have directly or indirectly antimicrobial properties (Giampieri et al., 2012)

Bullock and Kenney (1969) reported that the standard plate counts on $38.8 \%$ fat spreads stored at $7.2{ }^{\circ} \mathrm{C}$ for four weeks increased about one log cycle. The majority of the serum droplets were in the size range of 3 to 20 microns. In $30 \%$ fat spreads, however, where many of the serum droplets exceeded 50 microns, the standard plate count increased by three to four log cycles over the four-week storage period (Fig. 13).

Charteris (1996) also reported that significant increase in the standard plate count due to wide usage of dairy ingredients such as skim milk, butter milk, and SMP etc. in the formulation of table spread. Statistically, the type of spread, storage period and interaction between the significantly affected $(p<0.05)$ the changes in SPC in the product.

\section{Changes in yeast and mound count $(\mathrm{CFU} / \mathrm{g})$}

The occurrence of yeast and mold in dairy products is significant because they can cause spoilage, affect the bio-chemical changes and may also adversely affect public health. At low storage temperature yeast have competitive advantage compared to other spoilage microorganisms and therefore is of major risk of spoilage. The table 5 indicates that up to 20 days of storage there was no yeast and mold count found in LFS, strawberry LFS and Preservative LFS respectively. However, a steep rise was noticed for control LFS sample after 20 days of storage. The Preservative sample showed lower count of yeast and mold as compared to other 2 spread content of at the end of storage period. The increase in the count of yeast and mound can be attributed mainly to post pasteurization contamination. The finding in the present study also supported by report of Narayan and Gupta (2018) who reported that yeast and mould count in yoghurt fortified with strawberry pulp (Fig. 14).

Verma et al., (1998) also reported definite YMC increase in low fat spread after 30days and 10 days at $5^{\circ} \mathrm{C}$ and $10^{\circ} \mathrm{C}$, respectively. A highly negative correlation was observed between colour scores and yeast and mound counts indicating a definite effect of mound growth during storage. A similar negative correlation was also observed between yeast and mound counts and flavour scores as affected by period of storage. Statistical analysis revealed that the type of spread, storage days and their interactions significantly $(p<0.05)$ affected the changes in yeast and mold counts of all samples during storage

\section{Changes in coliform count}

The coliform count of the samples was found to be nil through the storage period which good hygienic condition during manufacture and storage of the product. Ghee based LFS was evaluated for storage life with $T_{1}$ (Control) - Low fat spread without strawberry powder and synthetic preservative, $\mathrm{T}_{2}(\mathrm{SS})$ Low fat spread with strawberry powder but without preservative, $\mathrm{T}_{3}$ (Preservative) - Low fat spread with synthetic preservative. With progress in the storage period total solid decreases while $\mathrm{pH}$, FFA, TBA, peroxide value, oiling off, and wheying off increases. None of these rendered the product unacceptable for the 60 days at $5^{\circ} \mathrm{C}$.the main cause of spoilage, especially in control sample, was found to be surface growth of yeasts and moulds. SPC in all samples increased and coliform count of the samples 
was found to be nil through the storage period which good hygienic condition during manufacture and storage of the product. The shelf life of the product was found to considerably influence by the presence of preservative.

\section{References}

Abdeldaiem, A. M., Jin, Q., Wang, X., Liu, R. 2014. Effects of $\mathrm{pH}$ values on the properties of buffalo and cow butterbased low-fat spreads. Grasas $y$ Aceites 65(3): 38-42.

AOAC. 1980 Official Methods for the Analysis of the Association of Official Analytical Chemist, 13th ED., A.O.A.C. Washington, D. C.

Babubhai, N. S. 1999. Technological studies on production of low fat sweetened dairy spread. M.Sc. Thesis, National Dairy Research Institute, (Deemed University), Karnal (HR).

Bhardwaj, R., Balasubramanyam, B. V., Mishra, D. and Papasani, A. 2017. Preservative effect of pomegranate peel extract on the keeping quality of cream based fat spread. Int. J. Pure App. Biosci., 5(6): 323-328.

Brunello, N. Mc Gauley, S. E., Marangoni, A. 2003. Mechanical properties of cocoa butter in relation to its crystallization behavior and microstructure. LebensWissen Technol., 36: 525-532.

Bullock, D. H., Kenney, AR. 1969. Effect of emulsion characteristics of a low-fat dairy spread on bacterial growth. $J$ Dairy Sci., 52: 625-628.

Charteris, W. P. 1996. Microbiological quality assurance of edible table spreads in new product development. J. Soc. Dairy Techno., 149: 87-98.

DeMan, J. M. and Wood, F.M. 1958. Oiling off properties of butter. J. Texture Stud 18: 303-318.

Deshmukh, M. S., Patil, G. R., Sontakke, A.
T., Kalyankar, S. D. and Padghan, P. V. 2003. Storage study of low fat spread from safflower milk blended with buffalo milk. J. of Dairy foods home sci., 22: 63-66.

Deshpande, D. 1998. Formulation of table spread from UF retantate of table spread from UF retentate. M.Sc Thesis, NDRI Deemed University, Karnal.

Devdhara,V. D., Murthi, T. N., Punjrath J. S. and Aneja R. P. 1991. Low calorie butter spreads from cream: Part II factors affecting its manufacture. Indian J. of Dairy Sci., 44: 116-125.

Dostalova, J. 2003 Low fat spread encyclopaedia of food sci and nutrition. 2 nd edition. Academic press, London, 6: 3617.

Feeney, E. L., Osullivan, A., Nuget, A. P., Mcnuty, B., Walton, J., Flynn, A., Gibney, E. R. 2017. Nutr. Diabetes, 7(2): 243.

Giampieri, F., Tulipani, S., Jose, M., Suarez, A., Jose, L., Mezzetti, B., Battino, M., 2012 The strawberry: Composition, nutritional quality, and impact on human health. 28(1): 9-19.

Ibrahim, S. A, El-dairy, S. V., FiKry, S. A. 1994.The keeping quality of low calorie butter made with adding Kareish cheese or sodium caseinate. Egypt J Dairy Sci., 22:47-58

Jiawei, Y., Ban, Z., Lu, Z. and Lu, H. 2019. The effect of the layer-by-layer (LBL) edible coating on strawberry quality and metabolites during storage. Postharvest Biology and Technology. 147: 29-38.

John, J. N., Tyagi, S. M. 2003. Development of low-fat paneer spread using fat replacer. Souvenirs, 5th International Food Convention, Mysore, India, p 15.

Kadivec, M., Leopold, M.M., Tijskens, Kopjar, M., Simcic, M., Tomaz, P. 2016. Modelling the colour of strawberry spread during storage, 
including effects of technical variations. Pol. J. Food Nutr. Sci., 66 (4): 271-276.

Kharb, S. 2007. Formulation of low fat table spread. Ph.D. Thesis. National Dairy Research Institute, (Deemed University), Karnal (HR).

King, R. L. 1962. Oxidation of milk fat globule membrane material. I.Thiobarbituric acid reaction as a measure of oxidized flavor in milk and model systems. J. of Dairy Sci., 45 (10): 1165-1171.

Lara, I., García, P., Vendrell, M. 2004. Modifications in cell wall composition after cold storage of calcium-treated strawberry (Fragaria $\times$ ananassaDuch.) fruit. Postharvest Biology and Technology, 34(3): 331-339.

Larsson, S. C., Hakansson, N., Naslund, I. 2006. Fruits and vegetables consumption in relation to pancreatic cancer risk: a prospective study. Cancer epidemiol biomarkers, 15: 301-305.

Lee, C. L., Huei-Lin, L. A., Lee W. A., ChaoKai, H. A., Hsueh, F. A., Pan J. Q.,, Chu, C. B., Chieh-Ting W. B., MingJu, C. C. 2018. Standards and labeling of milk fat and spread products in different countries. journal of food and drug analysis, 26: 469-480.

Machiex, J.J., Fleuriet, A., and Billot, J. 1990. Fruit phenolics. CRC Press, Boca Raton, FL.

Milivojevic, J., Nilkolic, M., BogdanovicPristov, J. 2010. Physical, chemical and antioxidant properties of cultivars and wild species of Fragaria and Rubes genera. J. pomology, 44: 169-170.

Narayana, M. D., Gupta, V. K. 2018. Storage changes and shelf life of strawberry set yogurt made by milk standardized using ultrafiltered skim milk retentate. International Journal of scientific and technology 7(8): 261-268.

Ofosu, I. W., Owusu, A. A., Mensah, W. A., and Oldham J. H., Oduro, I. 2011. Modeling the Formulation and Shelf Life of Avocado (Persea Americana) Fruit Spread American J. of Food Tech.,6(8): 661-673.

Olubunmi, B. A., Seun, F. A. and Funmilayo, T. A. 2013. Food value of two varieties of ginger Zingiber officinale commonly consumed in Nigeria, Hindawi publishing Corporation. ISRN Nutrition, 5p.

Parmar, P. and Khamrui, K. 2017. Development of process for the production of Arjuna herbal ghee from buffalo milk. Indian $J$. of animal sciences. 87 (2): 203-207.

Patange, D. 2006. Studies on manufacture of low fat spread using ghee. Ph.D. thesis, Mahatma Pule krishiVidyapeeth, Rahuri (MS).

Patange, D. D., Patel, A. A., and Kamble, D. K. 2015. Quality of ghee based low fat spread under various processing condition, 6th International conference on emerging technologies in food and nutrition for health management. ICETF, Souvenir.

Patange, D. D., Patel, A. A., Singh, R. R. B., Patil, G. R. 2013. Storage related changes in ghee-based low-fat spread Journal of Food Science and Technol., 50(2): 346-352.

Patel, A. 1982. Development of low-calorie protein rich table spread. Ph.D. Thesis, Kurukshetra University Kurukshetra (HR).

Prajapati, P. S. 1988. Technology of low fat spread manufacturing. Ph.D. Thesis. National Dairy Research Institute, Karnal.

Reddy, S. Y., Nalinakshi, M., Chetana, R. 2017.Fully hydrogenated vegetable oil as a stabilizer for low fat butter spreads. J. of food lipids, 6(3): 245- 
259.

Reddy, Y. K., Lakshminarayana, M., Sarma, K. S., Ranganadham, M. and Kumar, S. 2001. Storage related changes in flavour and certain chemical properties of chakka based butter spread. Indian Journal of Dairy Science, 54: 257-258

Sharma, S., Joshi, V. K., and Abrol, G. 2009. An overview on Strawberry [Fragaria $\times$ ananassa (Weston) Duchesne ex Rozier] wine production technology, composition, maturation and quality evaluation, Natural Product Radiance, 8(4): 356-365.

Snedecor, G. W. and Cochran, W.G. 1994. Statistical Method, 8th Ed.; Affiliated East-West Press: New Delhi.

Spurgeon, K. R., Seas, S. W. and Yang, J. O. 1973. Develop low fat dairy spread. American Dairy Rev, 32: 48-50.

Toyabhai, 2012. Development of an improved process of Production of herbal ghee from Buffalo milk using Arjuna extract. Thesis submitted to the National dairy research institute, Karnal.

Verma, R. B., Prajapati. P. S., Upadhyay, K. G., Thakar, P. N. 1998. Shelf life of cream based low-fat spread. XXIX Dairy Industry Conference, National Dairy Research Institute, Karnal, p 142.

Wright, A. J., Scanlon, M. G., Hartel, R. W., Marangoni, A. G. 2001. Rheological properties of milk fat and butter. $J$ Food Sci., 66:1056-1071.

Yildiz, H., Ercisil, A., Hegedus, M., Akbulut, E. F., Topdas, J. 2014. Bioactive content and antioxidant characteristics of wild (Fragaria $\times$ ananasassa Duch) fruits Turkey. 2014. J. of applied botany and food quality. 87: 274-278.

\section{How to cite this article:}

Londhe-Patil Prajakta Balasaheb, D. D. Patange, Suchita Bhosale, M. M. Yadav and Gaondhare, S. J. 2019. Storage Related Changes in Strawberry added Ghee based Low-Fat Spread. Int.J.Curr.Microbiol.App.Sci. 8(10): 24-42.

doi: https://doi.org/10.20546/ijcmas.2019.810.005 